\title{
VÁLLALATI FELELŐSSÉG ÉS TÁRSADALMI REAKCIÓK
}

\section{CORPORATE RESPONSIBILITY AND PUBLIC REACTIONS}

\author{
Kardos Péter \\ PhD, egyetemi adjunktus, Bloomfield College, NJ, USA \\ peter_kardos@bloomfield.edu
}

\begin{abstract}
ÖSSZEFOGLALÁS
A közvélemény a jogrendszer alakítása mellett a piacon keresztül közvetlenül is hatással van a vállalatok működésére. Fontos tehát megismerni, miként értelmezi a közvélemény a vállalati felelősséget, kit és hogyan büntetnének az emberek vállalati károkozás esetén. A tanulmány a pszichológia felől közelítve, empirikus eredményekre támaszkodva vizsgálja meg a vállalati normaszegésre adott társdalami reakciókat. Először a kollektív felelősség fogalmi rendszeréből kiindulva bemutatom, hogy miként válik el az okozói felelősség és az igazságérzet motiválta büntetés etikátlan vállalati viselkedés megítélésekor, majd összefoglalom az eddigi kutatási eredményeket a vállalaton belüli felelősség elosztásáról. A jogi és társadalmi környezet befolyása kapcsán pedig megmutatom, hogyan befolyásolja a közvélemény vállalati viselkedésre adott reakcióit a szabadpiaci ideológiában való hit.
\end{abstract}

\section{ABSTRACT}

As public opinion can shape the legal system and, through the market, influence corporate behavior, it is important to understand people's reaction to corporate transgression. In this paper we utilize a psychological approach and rely on empirical findings to investigate people's reaction to unethical corporate behavior. First, building on our understanding of collective responsibility I analyze the relationship between causal responsibility and justice motives in the corporate context. Next I summarize the empirical findings about how people assign and distribute responsibility within corporations. I also highlight the effect of social environment on justice motives and show how belief in free market ideology influences people's reaction to corporate transgression.

Kulcsszavak: vállalati felelősség, igazságérzet, kollektív felelősség, kollektív büntetés, szabadpiaci ideológia

Keywords: corporate responsibility, justice demand, collective responsibility, collective punishment, free market ideology 
A vállalati etika tudományos és gyakorlati elterjedése és a vállalati felelősség vizsgálata részben társadalmi elvárások hatására történt. Fontos ezért megismerni a közvélemény vállalati normaszegésekre adott válaszát. Egyrészt, az állampolgárok véleménye a választott képviselőkön keresztül befolyásolhatja a törvényalkotást. A közvélemény a piacon keresztül, fogyasztói döntések révén is hatással van a vállalatok viselkedésére. Emellett a közvélemény reakcióiban fellelhető mintázatok és az ítéleteket befolyásoló pszichológiai mechanizmusok minden bizonnyal a hatósági és jogi döntések mögött is megtalálhatóak.

A tanulmány két szempontból vizsgálja a vállalati normaszegésre adott reakciókat. Elöször a vállalati kollektív felelősségböl kiindulva megmutatom, hogy miként ítélkeznek az emberek a vállalatokról, és miként osztják fel a felelősséget a vállalaton belül. Ezután az ideológiai különbségek és a vállalati normaszegésre adott fogyasztói reakciók kapcsolatát tárgyalom. Saját eredményeinkre támaszkodva bemutatom, hogy miként befolyásolja a szabadpiaci ideológiában való hit a vállalatokkal szembeni fogyasztói ítéleteket.

A tanulmány a vállalati felelősséget nem morális, jogi vagy filozófiai alapon közelíti meg. A szemlélet pszichológiai és leíró. A morális ítéletek tapasztalati alapú modelljeit mutatja be, ahol a cél az emberek vállalati normaszegéssel kapcsolatos reakcióinak és büntetési szándékának pontosabb megértése.

A vállalatok alatt a nagyvállalatokat, részvénytársaságokat értjük. Ezekben a szervezetekben elválik egymástól az irányítás és a tulajdonlás, a szervezeti viszonyok befolyásolják a felelősség megállapítását. A nagyvállalati fókusz másik oka, hogy ezen intézmények müködése befolyásolja leginkább az emberek mindennapi életét.

\section{KOLLEKTÍV VÁLLALATI FELELŐSSÉG}

A vállalati felelősség egyik fontos kérdése, hogy magát a szervezetet vagy annak tagjait tartjuk-e felelősnek vállalati károkozás esetén. Ha az egész vállalatot kívánjuk büntetni, akkor ez felveti a kollektív felelősség kérdését. A kollektív felelösség három alapesetét különböztethetjük meg. Van, hogy egy szervezet minden egyes tagja vétkes, ezért elfogadható, hogy minden tagot felelösségre vonnak. A gazdaságban ez csak egyszemélyes vállalkozásoknál, kisebb cégeknél képzelhető el. Nagyvállalatoknál nem valószínü, hogy mindenki bünrészes volna, és ezért egységesen felelös lenne az okozott kárért.

A második lehetőség, hogy nem a szervezet egyes tagjait vonják felelösségre, hanem a szervezet egészét. A vállalatok büntetése gyakran esik ebbe a kategóriába. Viszont a szabályszegő viselkedést a vállalat egyes alkalmazottai követik el. Ezzel a vállalatra mint intézményre hárul a felelősség, hogy a hatóságok által kiszabható büntetések elkerülése céljából kontrollálja a szervezet tagjainak viselkedését (Dan-Cohen, 2010). A vállalat sok esetben tényleg felelősséggel tartozik 
a dolgozói tetteiért. Ez a vállalatok közösségi értelmezéséből ered, és ez a civil, bünügyi jog megközelítése.

A mindennapi felfogás ezt a közösségi szemléletet tükrözi, vagyis létező entitásként tekint a vállalatokra. Ezért tudjuk megkülönböztetni a Microsoftot az Apple-től, és emiatt tudunk vállalati információk alapján munkaerőpiaci és befektetési döntéseket hozni (Baer, 2010). Sok döntéshez elengedhetetlen ez a szemlélet. Például egy évtizedeken átívelö stratégiai terv elfogadása vagy egy hosszú távú hitel felvétele csak akkor értelmezhető, ha a cselekvés alanyaként magát a vállalatot tekintjük, nem pedig az egyes alkalmazottakat.

Annál valószínübb, hogy egységesen, egyénekhez hasonlóan ítélkezünk egy csoportról, minél inkább hasonlónak és összetartónak látjuk a tagjait. A csoportoknak ezt a tulajdonságát „entitativitás”-nak nevezzük (Hamilton-Sherman, 1996). Magas entitativitás esetén egy tagoktól függetlenül értelmezhető egységként tekintünk a csoportra, amitől belső koherenciát és kiszámíthatóságot várunk el. Egy ilyen csoportnál valószínübbnek tartjuk, hogy egyes tagok etikátlan viselkedéséhez a többiek is hozzájárultak valamilyen formában. Ezért magasabb entitativitású csoportok nagyobb eséllyel válnak kollektív felelösség és büntetés célpontjává (Lickel et al., 2003).

Az üzleti vállalkozásokra mint entitatív csoportokra tekinthetünk (ShermanPearcy, 2010). Sok vállalat egységes arculat és kultúra formálását tüzi ki célul, és ez kétségkívül hozzájárul a kiszámíthatóbb müködéshez. De ahogy az egységes arculat, az egyenruhák és az erős vállalati kultúra növelik az észlelt entitativitást, az befolyásolhatja a vállalat megítélését is. A magasabb vállalati entitativitás miatt az egyéni alkalmazottak etikátlan viselkedését jobban általánosítjuk az egész vállalatra, és ez szigorúbb ítéletekhez vezethet. Van, aki szerint ez így fair. Ha a vállalatok élvezni akarják az egyéneknek kijáró jogokat, mint például a szólásszabadságot, akkor viselniük kell az egyénekre alkalmazott szigorúbb felelősségtulajdonítást és ítéleteket is (Sherman-Pearcy, 2010).

A kollektív megközelítés azonban problémákat vet fel. Az egyik ilyen, hogy ha az egész vállalatot tartjuk felelősnek, akkor előfordulhat, hogy a részvényeseket büntetjük a menedzserek felelőtlensége miatt. A tulajdonosok pénzéből kifizetni a büntetést viszont kevés visszatartó erővel bír a menedzserek számára, vagyis a tulajdonosi és irányítói funkció szétválasztása csökkentheti az igazságszolgáltatás elrettentő szerepét. Amerikában a hatóságok gyakran figyelembe veszik, hogy ki viseli a büntetés következményeit. Ha úgy találják, hogy a részvényesek maguk is áldozatai az okozott kárnak, akkor gyakran eltekintenek a vállalat egészének, vagyis a részvényesek büntetésétől, és egyéni felelőst keresnek (Baer, 2010).

A vállalat kollektív büntetését a tulajdonosokon kívül más érintettek is megszenvedhetik. Az amerikai kormány gyakorlatilag felszámolta az Arthur Andersen könyvvizsgáló céget az Enronnál talált visszaélésekben betöltött szerepe miatt. Hogy megértsük a büntetés léptékét, világszerte majdnem négyszáz irodáról 
és nyolcvanötezer munkahelyröl beszélünk, ahol többek között kelet-európai titkárnők veszítették el az állásukat korrupt texasi menedzserek miatt. Vajon számít-e az ítéleteknél, hogy hány embert bocsájtana el a vállalat a büntetés esetén? Az emberek nem zárkóznak el a kollektív büntetés alkalmazásától, de valószínü, hogy az ártatlan érintettekre való hatás ismerete befolyásolja az ítéleteket.

A vállalat egészének büntetése felvet még egy problémát. A személyek állandóságával szemben a vállalatok mint csoportok szinte minden elemükben átalakulhatnak (Hamilton-Sherman, 1996). Sokszor előfordul, hogy a kár okozása és a felelösségre vonás közti időben felvásárolják a vállalatot. A korábbi menedzserek már nincsenek a cégnél, a mostani részvényesek korábban nem voltak tulajdonosok, és a felvásárlás során nem mindig derülnek ki a korábbi visszaélések. Kit vonjunk felelősségre? A vállalat egységének feltételezése és a vállalat egészének büntetése ebben az esetben már helyettesítő büntetés, ahol az elkövető helyett valaki mást vonnak felelősségre.

Ez a helyettesítő büntetés a kollektív büntetés harmadik formája. Itt a szervezetnek csak bizonyos tagjait vonjuk felelösségre a vállalat okozta kár vagy épp mások helyett. Ez akkor fordulhat elő, ha nehéz az elkövető azonosítása és felelősségre vonása, vagy a szervezeti döntési struktúra az elkövetőn kívül mások oksági felelősségét is felveti. Több okból is igazságosnak tarthatjuk olyanok felelösségre vonását, akik személyesen nem követtek el semmit. Morálisan felelösnek tartjuk például azt, aki utasítást ad az etikátlan viselkedésre, de azt is, aki bátorítja rá az elkövetőt. Ez a megbízói felelősség nem csak egyes személyekre vonatkozhat. Szervezeteket, sőt eszméket is hibáztatunk, amennyiben azokat az etikátlan viselkedéshez vezető célokkal azonosítjuk. Így merül fel szélsőséges ideológiák felelőssége a követőik által elkövetett büncselekmények kapcsán.

De azt is morálisan felelősnek tartjuk, aki ugyan aktívan nem járult hozzá a károkozáshoz, de nem tett meg mindent, hogy megakadályozza azt. Ez a mulasztás passzív felelőssége, és sokszor emiatt hibáztatjuk elkövetők családtagjait és barátait (Hamilton, 1986; Lickel et al., 2003). Azt gondoljuk, hogy ők megakadályozhatták volna, sőt, meg kellett volna akadályozniuk a bajt. Vállalatoknál is gyakran felmerül a mulasztás felelőssége. A respondeat superior, a felettes helyettes felelösségének elve, a római jogból származik, és ez alapján gyakran morálisan és jogilag is felelősségre vonják a vezetőket beosztottjaik vétségeiért.

\section{FELELŐSSÉG A VÁLLALATON BELÜL}

Míg a szervezeti folyamatok és kultúra alapján sokszor igazolható volna az egész vállalatra értelmezett felelősség, a jogrendszer alapvetően az egyéni felelősség felderítésére és az egyéni bünösség megállapítására alkalmas. Ennek megfelelően a jogi eljárások többnyire vétkes egyénekkel és az ő felelősségükkel foglalkoz- 
nak, nem pedig a szervezet egészének vagy egyes részlegeinek felelösségével. Maguk a vállalatok is gyakran védekeznek azzal normaszegés esetén, hogy nem a korrupt szervezeti gyakorlat a felelös, csak egyedi esetről, egyetlen alkalmazottról van szó. A valóságban viszont sokszor nehéz eldönteni, hogy a vállalaton belül ki a felelős az okozott kárért. A leíró, gyakorlati kérdés az, hogy miként osztják el az emberek a felelősséget egy etikátlanul viselkedő szervezeten belül. Ki a felelős, ha egy vállalat kárt okoz az érintettjeinek? A menedzser vagy a beosztottak? Felelős-e az igazgatótanács és a tulajdonosok?

Amikor kívülállók ítélkeznek egy vállalatról, egyenetlenül osztják el a felelősséget, amely a szervezeti struktúra tetején koncentrálódik. Ez megfelel a vállalat szervezeti hierarchiájából következő felelősségelosztásnak, ahol a magasabb pozíció rendszerint szélesebb döntési jogkörrel, több felelösséggel és magasabb jutalmazással jár. Ennek egyik csoportpszichológiai oka, hogy a vezetőkre a csoport prototipikus képviselőjeként és a csoportidentitás megtestesítőjeként tekintünk. Ha a vállalat etikátlan, akkor a vállalattal jobban azonosított vezetőt is nagyobb eséllyel látjuk etikátlannak, mint az alsóbb szintủ beosztottakat. Emellett a magasabb beosztású alkalmazottaktól nagyobb szakértelmet várunk el, a kockázatok pontosabb értékelését, valamint a beosztottak szupervízióját. Az a motiváció is gyakran müködésbe lép, hogy károkozásnál mindenképp bünöst akarunk találni. Beazonosítható felelős nélkül könnyủ célpont a vezető. Saját felméréseinkből azonban látszik, hogy nem a vezetők megbüntetése a legfontosabb cél. Kívülállók számára vállalati normaszegés megítélésekor mind a vállalati bocsánatkérés, mind pedig az anyagi kártérítés fontosabb volt, mint a vezetők megbüntetése (Kardos, 2016).

A vezetőkkel szembeni magasabb elvárásokat mutatja, hogy ha ugyanazzal a hanyagsággal vádolnak egy vezetőt és egy beosztottat, akkor a vezetőt hibásabbnak tartjuk (Hamilton-Sanders, 1992). Ebböl azt a következtetést vonhatjuk le, hogy nemcsak a felelösség elosztása torzít a vezető kárára, hanem a vezető szerep önmagában is felnagyítja a felelösséget.

Nehezíti az alkalmazottak felelősségének megállapítását, hogy sokszor felsőbb utasítást vagy rossz vállalati gyakorlatot követve okoznak kárt. Ha a károkozó viselkedéshez vezető szabályokat a vállalat felső szintjén hozták, akkor a belső döntési folyamatok és a szervezeti kultúra, vagyis a vállalat egészének felelőssége nagyobb, míg az egyéni alkalmazott felelőssége, döntési autonómia híján, kisebb lesz (French, 1984).

Az alkalmazottak normaszegéséből a felettes felelősségére is következtetünk. Minél nagyobb az utasítást kiadó felettes és a végrehajtó beosztott közti pozíciókülönbség, és minél nagyobb a vezető kontrollja, annál nagyobb oksági és morális felelösséget tulajdonítunk a felettesnek (Shultz et al., 1987). Úgy tủnik, hogy az elkövetők gyakori védekezése, miszerint csak utasítást követtek, az emberek általános felelősségtulajdonítási gyakorlatát tükrözi. 
A megvádolt vezetők gyakran azzal érvelnek, hogy közvetlen utasítási jogkör nélkül vagy direkt utasítás hiányában ők nem felelösek a beosztottak tetteiért. De leírt vagy kimondott utasítás nélkül is lehet irányítani, és ez sokszor épp a felelősség stratégiai elkerülését szolgálja. Ha nincs nyoma a károkozó viselkedésre vonatkozó utasításnak, nincs vezetői felelősség. Egyrészt ez a kódolt kommunikáció nem hatékony, mert félreértésekhez vezethet. Másrészt a kívülállók és a bíróság a közvetett utasítás kiadóját is felelősnek tartják. Sőt, még utasításra sincs szükség, elég a rossz példa mutatása. Eltolódik a felelösség, és kisebb büntetést szánunk a szabályszegő alkalmazottaknak, ha vállalati feletteseik hasonlóan viselkednek, vagyis a beosztottak csak őket másolták (Bauman et al., 2016).

Egy oksági és engedelmességi felelősség viszonyát vizsgáló kísérletben a résztvevők tiszt parancsára civileket mészároló katona, orvos utasítására rossz gyógyszert beadó nővér és politikai felettese megbízására törvénytelenséget elkövető alkalmazott esetét értékelték (Hamilton, 1986). A teljes, százszázaléknyi felelősséget kellett elosztani az elkövető, az utasítást kiadó felettes és a szervezet felső vezetése között. Bár a kísérletben részt vevők az elkövetőnek tulajdonították a legnagyobb felelősséget, az utasítást kiadó közvetlen felettest és a felső szervezeti vezetést is hibáztatták. A cselekvő felelősségét a cselekedetet kiváltó ok miatt, ami ebben az esetben egy másik személy, leértékeljük.

A vállalati felelősségelosztás egyik átfogó tanulmányában a szerzők különféle károkozó szcenáriókat készítettek (Sanders et al., 1996). Ezekben gyár károsította a környezetet, gyógyszercég hozott forgalomba veszélyes terméket, autógyár szegett meg biztonsági elöírásokat, és napilap nem közölte le egy üzem egészségkárosító gyakorlatáról szerzett információit. Továbbá mindegyik szcenáriónak többféle változata volt, amelyek abban különböztek egymástól, hogy vezető vagy beosztott volt-e az elkövető, hogy szándékosan, hanyagságból vagy véletlenül okozta a kárt, és hogy önállóan döntött-e, vagy pedig a felettesek utasítására vagy sugalmazására. A résztvevők ezután nullától száz százalékig értékelték az elkövető, a kollégák, a felettes és az egész vállalat felelősségét. Annál nagyobb felelösséget tulajdonítottak az elkövetőnek, minél magasabb volt a szervezeten belüli pozíciója, minél nagyobb volt a tett mögött észlelt szándékosság, és minél kevesebb volt mások befolyása a döntésre. Annál nagyobb volt a munkatársak és a felettes felelössége, minél nagyobb hatást gyakorolhattak a károkozó viselkedés végrehajtására, és minél magasabb volt a pozíciójuk a károkozóhoz képest. Érdekes, hogy a résztvevők direkt utasítás és sugalmazás esetén is számonkérték a felettes felelősségét. A vállalat egészének felelősségét az elkövető szándékossága vagy önállósága nem befolyásolta, csak a pozíciója: minél magasabb volt az elkövető vállalati pozíciója, annál nagyobbnak látták az egész vállalat felelősségét.

Hasonló eredményeket találunk a vállalati struktúra és felelősségelosztás kapcsolatát vizsgálva (Gibson-Schroder, 2003). Itt a kísérletben részt vevők először 
vállalati károkozásról olvastak, majd a vállalat szervezeti hierarchiáját és a vállalati szerepeket grafikusan bemutató ábra alapján értékelték az ügyvezető igazgató, a felsővezetők, az alkalmazottak, az igazgatósági tagok és teljes vállalati egységek felelősségét. A magasabb pozíció itt is nagyobb felelősséggel járt. Kivétel volt az igazgatótanács, amit a résztvevők alig hibáztattak. Emellett a résztvevők nagyobb felelösséget tulajdonítottak az egyéneknek, mint a vállalati egységeknek. Említésre méltó még, hogy a laposabb szervezetekben átlagosan nagyobb felelősséget tulajdonítunk a szervezet tagjainak, mint magasabb szervezeti struktúrákban (Gibson-Schroder, 2003). Elképzelhető, hogy a jobban strukturált szervezetekben nagyobb esély van a felelősség diffúziójára.

Fontos megjegyezni, hogy míg a kívülállók ítéleteiben a felelősség a szervezet felső szintjén koncentrálódik, a felelősség szervezeten belüli vizsgálatakor ennek sokszor az ellenkezőjét látjuk, mert a vezetők az alacsonyabb beosztású alkalmazottakat hibáztatják. Amikor kiderült, hogy az amerikai hadsereg hírszerzői az iraki Abu Graib börtönben gyanúsítottakat kínoztak és öltek meg, a közvélemény, részben a nyilvánosságra került dokumentumok alapján, a hadsereg vezetését és politikai irányítását hibáztatta. Végül csak néhány közlegényt ítéltek el, a vezetőket nem. Az egyetlen felelősségre vont magas rangú tiszt Janis Karpinski volt, akit tábornokból ezredessé fokoztak le.

\section{FELELŐSSÉG A VÁLLALATON KÍVÜL}

A vállalati károkozás felelőseit és okait nem csak a szervezeten belül lehet keresni. A szélesebb értelemben vett társadalmi, jogi környezet is hozzájárulhat az etikátlan vállalati viselkedéshez. Az országok eltérő jogrendszere, kultúrája és a gazdasági szektorok viselkedési normái közt található különbségek mind befolyásolják a vállalat viselkedését. Sokszor épp a lazább szabályozás, az érdekvédelmi szervezetek gyengesége, a munkaerő védtelensége, a hazaitól eltérő környezetvédelmi normák motiválják a vállalatok nemzetközi terjeszkedését. Ahol alacsonyabbak a vállalati működéssel kapcsolatos etikai elvárások, ott ugyanazt a káros vállalati gyakorlatot kevésbé ítélik el a fogyasztók.

A gazdasági szektorok között is különböznek az etikai elvárások. A pénzügyi és hitelválság okaként sokan például az intézményi környezetet is felelősnek tartották. Eszerint a felügyeleti szervek leépítése, a pénzintézeti jogszabályok fellazítása, a túlzott kockázatvállalásra ösztönző gazdaságpolitikai döntések mind hozzájárultak a válság kialakulásához, ahogy a közgazdasági és üzleti tudományokban uralkodó homo oeconomicus szemlélet is.

Még a piac és a vállalatok szabadságát hangsúlyozó szabadpiaci elméletben is meghatározó szerepet kap a társadalmi és jogi környezet a vállalatok viselkedésének alakításában. A szabadpiaci elmélet szerint egy vállalat azáltal teljesíti erköl- 
csi kötelezettségeit, ha betartja a törvényeket; azon felül nincsen más társadalmi felelőssége, nem kell morális önkontrollt gyakorolnia (Friedman, 1970/2002).

De milyen következményekkel jár, ha a jogszabályokat hibáztatjuk a vállalatok etikátlan viselkedéséért? Egyfelől, a vállalatok morális önfelmentésként a törvényhozókra háríthatják a felelősséget károkozó veselkedésükért. Másrészt viszont, a választópolgárok a kártékony vállalati múködésre válaszul olyan jogszabályok bevezetését támogathatják, amelyek megelőzik a hasonló esetek megismétlődését.

\section{SZABADPIACI IDEOLÓGIA ÉS FOGYASZTÓI ÍTÉLETEK}

A társadalmi környezet a fogyasztói reakciókban betöltött szerepe miatt is lényeges. A kulturális és ideológiai különbségek előre jelezhetik a vállalati normaszegés kiváltotta ítéleteket. Például ugyanazon vállalati normaszegésért a japán fogyasztókhoz képest az amerikaiak nagyobb felelősséget tulajdonítanak az elkövető közvetlen felettesének, míg a japán fogyasztók a vállalat egészének felelősségét értékelik nagyobbra, mint az amerikaiak (Sanders et al., 1996).

Központi szerepet töltenek be a vállalati viselkedésre adott fogyasztói reakciókban a gazdasági rendszerrel, a piac müködésével kapcsolatos hiedelmek, mint például a piac hatékonyságába és a piaci mechanizmusok igazságosságába vetett hit (Jost et al., 2003).

A szabadpiaci ideológia szerint, amellyel az amerikaiak és nyugat-európaiak többsége egyetért, a vállalatok szabad müködése és a piaci reguláció leépítése szolgálja legjobban a piac fejlődését és a társadalmi jólétet. Nincs szükség a vállalatok intézményi szabályozására, sem pedig a vállalatok morális önkontrolljára, mivel a közvélemény igazságérzete elegendő ahhoz, hogy az etikátlanul viselkedő vállalatokat jobb belátásra bírja, és a társadalom számára kedvező magatartás felé terelje (Friedman, 1970/2002; Rothbard, 1986). Eszerint a fogyasztók elfordulnak a társadalmi normákat megsértő vállalatoktól, és bojkottálják a termékeiket. Profitérdekeik miatt a vállalatok pedig korrigálják a viselkedésüket, és követni fogják a társadalmi elvárásokat.

Az érvelés helyessége a közvélemény ítéletein múlik. Azon, hogy képesek-e a fogyasztók elfogulatlan igazságot szolgáltatni a piacon keresztül. Mivel a szabadpiaci ideológia híveinek volna leginkább érdeke a piaci igazságszolgáltatás fenntartása, tölük várnánk el a legerősebb reakciót etikátlan vállalati viselkedés esetén. A szabadpiaci ideológia mögött meghúzódó értékrendszer miatt azonban ennek az ellenkezőjét várhatjuk.

Elméleti munkák és empirikus eredmények alapján a szabadpiaci ideológia értékrendszerében az önérdekkövetés és hatalom tölt be kiemelt szerepet, míg az univerzalizmus, egyenlőség és jóindulat értékei kevésbé fontosak (Friedman, 1970/2002; Kasser et al., 2007). Amennyiben ezek az értékek - az önérdekkö- 
vetés fontossága, valamint az univerzalizmus, egyenlőség és jóindulat leértékelése - kifejezésre jutnak a fogyasztók ítéleteiben, akkor a szabadpiaci ideológia hívei elfogultak lesznek a saját érdekhez és saját csoporthoz köthető vállalatok javára a saját érdekhez nem köthető vállalatokkal szemben. Ezt a hipotézist egy kísérletsorozattal teszteltük (Kardos et al., 2016).

Három kísérletben amerikai résztvevők különböző vállalati normaszegésekröl olvastak. A kísérleti kondíciótól függően a normaszegő vállalatról vagy azt írtuk, hogy hazai (amerikai), vagy azt, hogy külföldi (kínai az első és második kísérletben, francia a harmadik kísérletben). Ezután megmértük, hogy a résztvevők mekkora kártérítést tartanak igazságosnak, milyen súlyos ítéletet szabnának ki a vállalat vezetőire (első és harmadik kísérlet), illetve, hogy szigorítanák-e a vállalatok szabályozását (második kísérlet). Végül megmértük a résztvevők szabadpiaci ideológiában való hitét, politikai szimpátiáját és nemzeti identitásának erősségét.

Az eredmények egybehangzóan mutatták, hogy a szabadpiaci ideológiában való hit és a vállalat nemzeti hovatartozásának kölcsönhatása szignifikánsan befolyásolta az igazságérzetet és a szabályozási reformtörekvéseket. A szabadpiaci ideológia elkötelezett hívei kisebb büntetést és kevésbé szigorú szabályokat javasoltak, ha az etikátlanul viselkedő vállalat hazai volt, mint ha külföldi. A szabadpiaci ideológiában kevésbé hívő résztvevőknél nem találtunk ilyen részrehajlást. Az eredmények nem a politikai szimpátia és a nemzeti identitás melléktermékei voltak - azoktól függetlenül, azokat kontrollálva kaptuk öket.

A közvélemény reagál a vállalatok normaszegő viselkedésére, azonban annak mértékében, hogy mennyire elkötelezett híve a szabadpiaci ideológiának. Elfogult lesz igazságérzetében azon vállalatok iránt, amelyeket hazainak észlel, szemben azokkal, amelyeket külföldinek. A szabadpiaci ideológiában való hit torzítja a fogyasztói ítéleteket, amelyek önmagukban nem vezetnek piaci igazságossághoz.

\section{5. ÖSSZEGZÉS}

A vállalati felelősségről szerzett eddigi ismeretek alapján úgy tủnik, hogy az emberek igazságosnak és hatékonynak tartják kollektív büntetés kiszabását. Ítéleteikben figyelembe veszik a vállalatokon belüli kapcsolatok rendszerét, és nem csak az elkövetőt tartják morálisan felelösnek és büntetendőnek. Másrészt a vállalat egészének büntetése azt mutatja, hogy a vállalatokat a személyekhez hasonló entitásnak látjuk. Egyelöre keveset tudunk a kollektív büntetés szervezeten belüli megítéléséről, ahogy azt sem tudjuk, van-e a kollektív vállalati büntetésnek elrettentő hatása. Ha vállalaton belül keresünk felelőst, a kívülállók rendszerint a felsőbb pozíciókban lévőket hibáztatják. Paradox módon, a vállalatok és vezetőik azonosítása révén, ez is hozzájárulhat a vállalatok kollektív büntetéséhez. 
A külső, társadalmi környezet szerepét vizsgálva azt látjuk, hogy az ideológiai különbségek is befolyásolják a fogyasztói reakciókat. Különösen fontos ez a szabadpiaci ideológia esetén, amely a fogyasztói reakciók révén kívánja megoldani a piaci regulációt és fenntartani a társadalmi igazságosságot. A fogyasztók vállalati normaszegésre adott válasza a szabadpiaci ideológiában való hit függvényében elfogult a hazai vállalatok javára a külföldiekkel szemben.

A vállalati felelősség a gazdaságetika egyik központi témája, amely régóta foglalkoztatja a filozófusokat, jogászokat és közgazdászokat. A morális és normatív szemlélet mellett fontos a pszichológiai megközelítés is. Ennek segítségével ismerjük meg az emberek mindennapi ítéleteit, és ezáltal értjük meg az ítéletek mögött rejlő motivációt. A közvélemény vállalati normaszegésre adott válaszait kutatva megérthetjük a szervezeti felelösségre vonás folyamatát, a jogi döntéseket és a közvéleményt befolyásoló motívumokat, és mindez segíthet a vállalatoknak elöre jelezni a vétségeik következményeit.

\section{IRODALOM}

Baer, M. H. (2010): Organizational Liability and the Tension between Corporate and Criminal Law. Journal of Law and Policy, 19, 1-14. https://papers.ssrn.com/sol3/papers.cfm?abstract_ id $=1933851$

Bauman, C. W. - Tost, L. P. - Ong, M. (2016): Blame the Shepherd Not the Sheep: Imitating Authorities Absolves Subordinates of Moral Responsibility. Organizational Behavior and Human Decision Processes, 137, 123-131. https://www.marshall.usc.edu/sites/default/files/tost/intellcont/Bauman\%20Tost\%20Ong\%202016-1.pdf

Dan-Cohen, M. (2010): Sanctioning Corporations. Journal of Law and Policy, 19, 15-43. https:// papers.ssrn.com/sol3/papers.cfm?abstract_id $=1769262$

French, P. A. (1984): Collective and Corporate Responsibility. New York: Columbia University Press

Friedman, M. (1970/2002): The Social Responsibility of Business Is to Increase Its Profits (first published in The New York Times Magazine). In: Hartman, L. P. (ed.): Perspectives in Business Ethics. Boston, MA: McGraw Hill. 225-230. DOI: 10.1007/978-3-540-70818-6_14, http://umich.edu/ thecore/doc/Friedman.pdf

Gibson, D. E. - Schroeder, S. J. (2003): Who Ought to be Blamed? The Effect of Organizational Roles on Blame and Credit Attributions. International Journal of Conflict Management, 14, 95-117. https://bit.ly/2ti9uMc

Hamilton, D. L. - Sherman, S. J. (1996): Perceiving Persons and Groups. Psychological Review, 103, 336-355. DOI: 10.1037//0033-295x.103.2.336, https://www.researchgate.net/publication/14562524_Perceiving_Persons_and_Groups

Hamilton, V. L. (1986): Chains of Command: Responsibility Attribution in Hierarchies. Journal of Applied Social Psychology, 16, 118-138. DOI: 10.1111/j.1559-1816.1986.tb02283.x

Hamilton, V. L. - Sanders, J. (1992): Responsibility and Risk in Organizational Crimes of Obedience. In: Staw, B. M. - Cummings, L. L. (eds.): Research in Organizational Behavior. Greenwich, Conn: JAI Press, 49-90.

Jost, J. T. - Blount, S. - Pfeffer, J. et al. (2003). Fair Market Ideology: Its Cognitive-motivational Underpinnings. Research in Organizational Behavior, 25, 53-91. DOI: 10.2139/ssrn.441005, 
https://www.researchgate.net/publication/4893725_Fair_Market_Ideology_Its_Cognitive-Motivational_Underpinnings

Kardos P. (2016): A szabadpiaci ideológia és a vállalatok nemzeti hovatartozásának hatása az igazságérzetre, a civil akciókra és az érzelmekre. (Doctori disszertáció.) Budapest: BCE DOI 10.14267/phd.2016035, http://phd.lib.uni-corvinus.hu/922/

Kardos P. - Leidner, B. - Zsolnai L. et al. (2016): The Effect of the Belief in Free Market Ideology on Redressing Corporate Injustice. European Journal of Social Psychology, 46, 661-779. DOI: 10.1002/ejsp.2222

Kasser, T. - Cohn, S. - Kanner, A. D. (2007): Some Costs of American Corporate Capitalism: A Psychological Exploration of Value and Goal Conflicts. Psychological Inquiry, 18, 1-22. DOI: 10.1080/10478400701386579, http://www.academia.edu/24470500/Some_Costs_of_American_Corporate_Capitalism_A_Psychological_Exploration_of_Value_and_Goal_Conflicts

Lickel, B. - Schmader, T. - Hamilton, D. L. (2003): A Case of Collective Responsibility: Who Else Was to Blame for the Columbine High School Shootings? Personality and Social Psychology Bulletin, 29, 194-204. DOI: 10.1177/0146167202239045

Rothbard, M. N. (1986): Protectionism and the Destruction of Prosperity. Auburn: Mises Institute, https://mises.org/library/protectionism-and-destruction-prosperity

Sanders, J. - Hamilton, V. - Denisovsky, G. et al. (1996): Distributing Responsibility for Wrongdoing inside Corporate Hierarchies: Public Judgments in Three Societies. Law \& Social Inquiry, 21, 815-855. DOI: 10.1086/492564, https://www.researchgate.net/publication/ 249479041_Distributing_Responsibility_for_Wrongdoing_Inside_Corporate_Hierarchies_ Public_Judgments_in_Three_Societies

Sherman, S. J. - Percy, E. J. (2010): The Psychology of Collective Responsibility: When and Why Collective Entities Are Likely to Be Held Responsible for the Misdeeds of Individual Members. Journal of Law and Policy, 19, 137-170. https://brooklynworks.brooklaw.edu/cgi/viewcontent. cgi? article $=1101 \&$ context $=\mathrm{jlp}$

Shultz, T. R. - Jaggi, C. - Schleifer, M. (1987): Assigning Vicarious Responsibility. European Journal of Social Psychology, 17, 377-380. DOI: 10.1002/ejsp.2420170314, https://www.researchgate.net/publication/230106771_Assigning_vicarious_responsibility 